NGTT Deel 54, Nommers $3 \& 4$, September en Desember 2013

Cilliers, Johan ${ }^{1}$

Stellenbosch University

\title{
The social impact of religious communities: the case of the Huguenots in South Africa ${ }^{2}$
}

\begin{abstract}
This paper takes a brief look at the history of the Huguenots in South Africa as an example of the social impact of religious communities. Arnold van Gennep and Victor Turner's theory of liminality is utilised to structure the paper as a discussion of three phases of history, namely separation, liminality, and aggregation. The paper concludes with some remarks concerning the relationship between power and religion.
\end{abstract}

\section{The Huguenots: a CASE STUdy in Liminality}

How should we evaluate the social impact of the Huguenots as a religious community in South Africa? Their history could obviously be described from a variety of angles, using different research methodologies. Whatever route one follows, a responsible, hermeneutical dialogue with the past is of pivotal importance, as we often tend to apply a reduced form of remembrance, a selective memory, if not a total amnesia. ${ }^{3}$ On the one hand, we should acknowledge the vulnerability and weakness of our acts of memory; on the other hand we should also embrace the potential of memory to interpret the past in a hermeneutically responsible manner. ${ }^{4}$ Memory is an important link to the past. But memory can also be abused in various ways, for instance, on a pathological and therapeutic level, on a practical level (especially in terms of finding and defending our identity), and on an ethical-political level. ${ }^{5}$

1 Professor in Homiletics and Liturgy at the Faculty of Theology, University of Stellenbosch, South Africa.

2 Paper delivered at the Summer School in Berlin, Humboldt University, $31^{\text {st }}$ May to $4^{\text {th }}$ June 2012, on the theme: The social impact of religious communities.

3 An interesting example of this search for a responsible hermeneutical dialogue with the past can be seen in the discourse between Pieter Coertzen and Philip Denis, both eminent historians. Denis has made the claim that the historical picture that has been painted of the Huguenots might represent a myth, invented to strengthen the identity of the Afrikaner, especially after the dawn of democracy in 1994 and the loss of political power by the Afrikaner. He states: "South Africa has now entered another era. The Afrikaner people, who developed the Huguenot myth as a way to strengthening their identity, have lost their leading position in the government of the country. This new situation creates the conditions for a more critical appraisal of the role of the Huguenots in South African history." Philip Denis, The Cape Huguenots and their Legacy in Apartheid South Africa. In: Bertrand Van Ruymbeke and Randy J Sparks eds., Memory and Identity. The Huguenots in France and the Atlantic Diaspora (Columbia: University of South Carolina Press, 2003), 303. Denis strongly suggests that the Huguenots were in fact not welcome at the Cape, and did not readily fit into the structures of power of the day, to which Coertzen responds by quoting several documents wherein the Huguenots (or at least some of their leaders) express their thankfulness for being able to exist and express their religious freedom in their new homeland. Cf Pieter Coertzen, The Huguenots of South Africa in documents and commemoration. Nederduitse Gereformeerde Teologiese Tydskrif Deel 52, Nommers 3\&4, September \& Desember 2011, 301-324.

4 Paul Ricoeur, Memory, history, forgetting (Chicago: University of Chicago Press, 2004), 21.

5 Robert Vosloo, Reconfiguring ecclesial identity: In conversation with Paul Ricoeur. Studia Historiae Ecclesiasticae. Journal of the Church History Society of Southern Africa. 2007, 32 (1). 273-293. 
NGTT: Oopbron - http://ngtt.journals.ac.za

In this paper, I have opted to utilise the concept of liminality as a lens through which to view this fascinating part of history. This term was coined in 1909 by Arnold van Gennep, when he used the term limen (threshold, outlines, margins) in describing human rituals marking the passage from one life phase to another. Van Gennep distinguished a threefold pattern of rites of passage, namely preliminal, liminal and postliminal stages functioning respectively as separation from, transition to, and incorporation into a social or cultural group. The liminal phases in particular, he noted, are "transitional periods which sometimes acquire a certain autonomy" and which are therefore to a certain degree characterised by uncertainty and instability. 6 But this unstable, transitional, liminal phase is critical for the regeneration accomplished in the social world through rites of passage, particularly those of death and rebirth.7

Since Van Gennep several other authors have made use of the concept. ${ }^{8}$ Most prominent among these is Victor Turner, who sixty years later also distinguished between the stages of separation, liminality, and aggregation. Turner extended the liminal phase in his The Ritual Process (1969), distinguishing two forms of "human interrelatedness", namely liminality and "the status system", which exist in a tension characterized by a long list of opposing terms, e.g. transition/state, homogeneity/heterogeneity, absence of property/property, heteronomy/ degrees of autonomy, humility/just pride of position, and nakedness or uniform clothing/ distinctions in clothing. ${ }^{9}$ In the liminal stage an alternative form of human interrelatedness can come into existence. To describe this, Turner made use of the religious image of "pilgrimage," which is essentially anti-structure and anti-status quo, but ultimately culminates in the formation of a new community. Turner describes this community with the Latin word communitas - which can in turn become a new structure or new status quo that may eventually need to be deconstructed. ${ }^{10}$

6 Arnold van Gennep, The Rites of Passage, Transl. MB Vizedom and GL Caffee (London: Routledge and Kegan Paul, 1960), 192f.

7 Van Gennep originally understood liminality in terms of regeneration, viewing “'regeneration' as a law of life and of the universe: the energy which is found in any system gradually becomes spent and must be renewed at intervals... this regeneration is accomplished in the social world by the rites of passage given expression in the rites of death and rebirth." Further characteristics of this in a sense autonomous phase are the engagement and the novitiate. Van Gennep, The Rites of Passage, viii.

8 Paul Tournier refers to liminality as being en route: having left your home but not yet having arrived at your destination. Paul Tournier, A Place for You (New York: Harper and Row, 1968), 163. It is the experience of being in limbo, like the time spent high above the clouds in an airplane, between take-off and landing. Eugene Peterson uses the striking metaphor of a trapeze artist swirling through space, in transit through mid-air, having been released from the arms of fellow trapeze artists and expecting to be caught in the firm and faithful grip of those waiting. Eugene Peterson, A Long Obedience in the Same Direction: Discipleship in an Instant Society (Downers Grove, IL: Inter-Varsity Press, 2000), 20.

9 Victor Turner, The Ritual Process: Structure and Anti-structure (Chicago: Aldine Publishing Co., 1969), $33 \mathrm{f}$.

10 V. Turner, and E. Turner, Image and Pilgrimage in Christian Culture: Anthropological Perspectives (Oxford: Basil Blackwell, 1978), 64 f. As two pertinent examples Turner refers to the early Franciscan order, and the communitates of artists, jesters, and prophets. According to Turner, these forms of communitates normally function on the margins of society, challenging structures of power related to law, property, status, and position. Liminal communitates in their symbols and beliefs refer to the marginal. Yet they are paradoxically also related to the structures of the status system, as can be clearly seen, for instance, in the court jester, who is simultaneously an insider and an outsider at the court. Turner and Turner, Image and Pilgrimage in Christian Culture, 108. Cf. also J.H. Cilliers, "Worshipping in the 'InBetween' Times of Transition: Reflections on the Liminality of Liturgy," in A Faithful Witness: Essays in Honour of Malan Nel (Wellington: Bybel Media, 2009), 167-79. 
NGTT Deel 54, Nommers $3 \& 4$, September en Desember 2013

It is fascinating to note that the same basic movements alluded to by Turner, namely separation, liminality, and aggregation, can be seen in a dramatic mural depiction (9 meters long; 1.8 meters high) erected on $6^{\text {th }}$ May 1942 on the wall of the Town Library in Stellenbosch in remembrance of the Huguenots. On the left, the history of the persecution; in the centre, the journey to South Africa by boat; and on the right, the establishment of a new order can be discerned. Obviously these three movements - we could also call them diaspora, liminality, and new order - are historically intertwined.

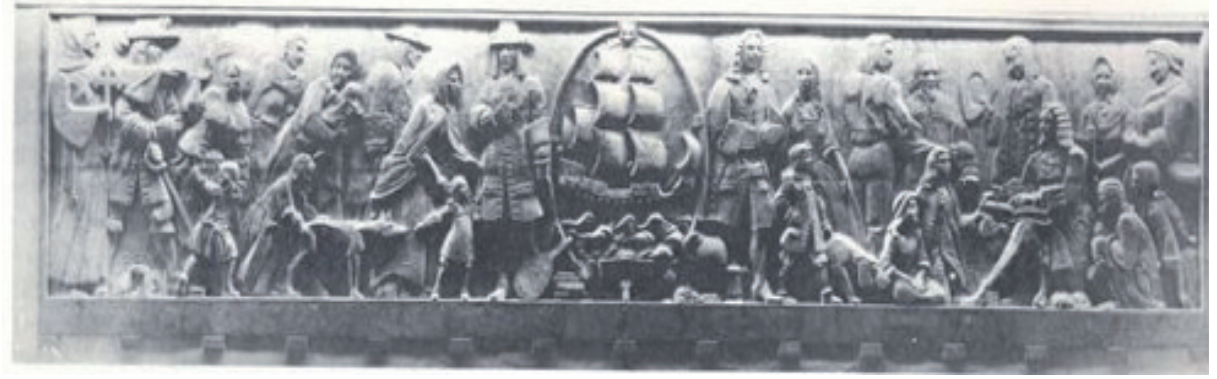

\section{The HuguenOtS: A PEOPLE IN DIASPORA}

The first stage that Turner refers to is that of being separated from the status quo - as can be seen on the left side of the wall of remembrance. On the far left a hooded figure holding a cross (representative of religious and ecclesial power) points the refugees away from their homeland. Next to him stands a soldier, with sword ready to be drawn (representative of the political power). Clearly the two powers are in collaboration here - threatening and persecuting the "others", i.e. those who do not fit into the "own" religious system. The refugees back away - a woman holds up her hand in defence, sheltering a young child at her feet. Other figures flee, one woman holding a baby, a boy urging his dog along. In the background, soldiers stand watching this process of exile.

Even a brief look ${ }^{11}$ at the bloody history of the Huguenots clearly illustrates this phase of separation. They were truly a people in diaspora for many decades and centuries, also before they came to South Africa. It is in fact hardly possible to understand the Huguenots of South Africa without also understanding their historical European background, and specifically the era of the Reformation. One of the outcomes of the Reformation was that a large number of Reformed congregations sprang up in France, especially after 1555, with further growth after 1559 when the first synod was formed. The influence of the work of Luther and in particular Calvin was evident in France at the time. ${ }^{12}$ The Name "Huguenot" was given to the French Reformed Church around 1560, although the meaning of the name is not quite clear. Some scholars believe that it is derived from the Swiss-German name "Eidgenossen" (i.e. partners in oath) - which became "Huguenot" in French, while others relate the name to a derogatory description indicating a group of people who were raucous and disruptive. ${ }^{13}$

11 Condensed from Pieter Coertzen's standard work on the Huguenots, Die Hugenote van Suid-Afrika 16881988 (Kaapstad: Tafelberg, 1988), 3-71.

12 Calvin had to flee France in 1534, but afterwards transformed a rather fragmented religious movement into a structured and confessional church.

13 For a detailed discussion of the origins of the name, cf. Coertzen, Die Hugenote, 16-17. 
NGTT: Oopbron - http://ngtt.journals.ac.za

Whatever the case, the Huguenots consolidated into a political power by 1560 after some of the aristocrats in France became Protestants. This in turn led to the religious wars of 1562 -1598. The infamous murders during "Bartholomew Night" were a bloody episode from these years of conflict between Roman Catholics and Huguenots.

In 1589 a Huguenot, Henry of Navarre, became King of France - but he converted to Roman Catholicism in 1593. On 13 April 1598 King Henry proclaimed the Edict of Nantes, granting religious freedom, and this led to some years of seemingly peaceful co-existence between Catholics and Huguenots in France. This however, did not last long, as King Henry was assassinated on $14^{\text {th }}$ May 1610, after which the privileges of the Huguenots were subsequently eroded. In 1661 King Louis XIV became king and eventually recalled the Edict of Nantes, resulting in the persecution of the Huguenots - once again.

About 200000 of the 2 million Huguenots in France fled from their home country. Some of those remaining became Catholics, but many joined the underground "Church of the Wilderness" (I'Église du Désert). About 70000 Huguenots fled to the Netherlands. The Dutch East India Company (DEIK) saw the opportunity and recruited some Huguenots to go to South Africa, where a post was established to provide fresh food for ships passing on their way to India. Between 1688 and 1690 about 180 Huguenots were transported to the Cape by ship - a rather perilous enterprise at the time, often resulting in several deaths en route due to storms, pirates, or malnutrition. Other ships followed, so that a total of about 250 Huguenots ultimately reached the Cape of Good Hope. Of these early refugees, some returned to Europe, but the majority stayed and became part of the history of the continent of Africa.14

\section{The Huguenots: in a StATE of Liminality}

The wall of remembrance depicts the second phase of the Huguenot's history in a striking manner, placing a ship in the centre - a symbol of being en route, of not having reached your destination, in short: of liminality. The ship sails on tempestuous waves, indicative of danger and chaos. But situated at the foot of this panel one can also see the symbols of that which the Huguenots brought with them, as an aesthetical depiction of their ultimate contribution to the South African society - a musical instrument, books (including the Bible), a bunch of grapes (symbolising their expertise in viticulture), two vases filled with corn and wine.

This phase of transition did not end when the Huguenots set foot in the Cape; in fact, they were in limbo for many years to come. It is a significant that the Huguenots - who, based on their religious convictions, opposed those in power in their home country - also clashed with the powers in government very shortly after arriving at the Cape. The same spirit of liberty that drove them to confront the authorities in Europe seemed to prevail in their new surroundings. In one of the discussions of the Political Council in the Cape, Simon van der Stel, who was Governor at the time, referred to the "Francoisen impertinentën" (French impertinence) and "comploterie" (intrigues). On a plaque in the Huguenot Museum in Franschhoek the refugees

14 The author of this paper is also a descendant of the Huguenots. His surname, Cilliers, is a French word that literally means "keeper of the vineyard," or "maker of wine". He is the tenth generation after the first Cilliers couple arrived on the ship Reijgersdaal at the Cape in 1700 (Josué and Elizabeth - they were, obviously, winemakers). One of his forefathers, Sarel Cilliers (the fifth generation after Josué and Elizabeth), played a major role in the so-called Battle of Blood River, and was seen as an important spiritual leader of the Voortrekkers who journeyed inland toward the northern borders of what is now South Africa. 
NGTT Deel 54, Nommers $3 \& 4$, September en Desember 2013

are described as a "wilful and rebellious people"! The tension ran so high that the Dutch Government became reluctant to accept more French refugees at the Cape. ${ }^{15}$ The Dutch Government even distrusted and resisted the French petition to form their own congregation, suspecting that they would join arms with the French if they ever attacked the Cape! ${ }^{16}$

Perhaps these tensions can best be illustrated by two incidents. When Joshué and Elizabeth Cilliers, ${ }^{17}$ arrived at the Cape in 1700, Willem Adriaan van der Stel, Governor at the time, and many of the influential officials of the Dutch East India Company owned and farmed their own farms - not only in contravention of the policies of the DEIC, but also putting many other, poorer farmers out of business. In 1706 a petition was drafted that described, inter alia, incidents of bribery, coercion and corruption perpetrated by Van der Stel and several of his officials. Those in power reacted swiftly and in turn drew up a letter that stated that everybody was satisfied with the government's administration, and that Van der Stel himself had an impeccable and honest character - a laudation that was to be signed by all citizens! People, who refused to sign, were threatened with eviction from their land. Although some, perhaps even the majority, did sign this document out of fear of losing their land, the outcome was that Willem Adriaan van der Stel was re-called from his post and had to return to the Netherlands.

The second incident concerns an interesting, if not infamous character called Estienne Barbier. He originally hailed from Orleans (where the Cilliers' couple also came from), and was captured and incarcerated by the Dutch Government because he accused an officer of corruption. Barbier has been described as "... a social bandit... someone who does something which is regarded as criminal by the State or the local rulers, but who is not considered to be a criminal, or to have acted against local conventions, by the population. He is protected by the people, though he is frequently a lone wolf living on the margins of society."18

For many, Barbier became a type of Robin Hood, fighting for the rights of the marginalised and oppressed people, a freedom fighter in his own right. Barbier managed to escape from prison (the famous "Kasteel" - Castle - still to be seen in Cape Town today), and found refuge on the farm of the widow Elizabeth Cilliers. He was however captured after some months, and suffered a particularly cruel punishment: he was crucified next to a busy road, and then dismembered and his body parts displayed in various public places.

Clearly the Huguenots did not readily "fit in" with the status quo in the Cape, at least not initially. Their strong religious convictions undoubtedly played a part in this, and had a clear, and sometimes dramatic, social impact. It is interesting to note that some parallels have been drawn between the Huguenots and the slaves in the Cape - "they had been both aliens and uprooted people in a foreign land." ${ }^{\prime 1}$ It is a known fact that many persecuted Huguenots were forced to serve as galley-slaves on ships, and that both the Huguenots and the slaves were brought to the Cape to serve the general economic goals and policies of the Dutch East India

15 Pieter Coertzen, The Huguenots: Origins, settlements and Influence. The story of a Refugee People.

Proceedings of the $3^{\text {rd }}$ International Huguenot Conference September 2002. Bulletin 39, Huguenot Society of South Africa. 7-24.

16 C. Graham Botha, The French Refugees at the Cape (Cape Town: Struik, 1970), 40.

17 The progenitors of the author of this article.

18 Penn, quoted in CN van der Merwe, Die "waarheid" omtrent Estenne Barbier. In Rondom Roy - Studies opgedra aan Roy H Pheiffer, Reds CN van der Merwe e.a. (Universiteit van Kaapstad: Kaapstad, 1994), 91.

19 Hannes Adonis, The French Huguenots and the slaves. Proceedings of the $3^{\text {rd }}$ International Huguenot Conference September 2002. Bulletin 39, Huguenot Society of South Africa. 24. 
NGTT: Oopbron - http://ngtt.journals.ac.za

Company. Fresh food had to be produced for passing ships, and for this the expertise of the Huguenots proved to be valuable. As a matter of fact, it was a prerequisite for Huguenots to come to the Cape - they had to be farmers (including those experienced in cultivating grapes) or carpenters.

The Huguenots were not allowed to bring any possessions with them, and although land was allocated to them for farming, they actually only became "legal" land owners after many years of farming on these lands. ${ }^{20}$ If they chose to return to Europe after 5 years they were not permitted to take any possessions besides that which they had on their person back with them. They then also had to pay the standard fair for the journey back home!

The Huguenots were never - at least as a group - in any official positions of power. The Dutch ruled the Cape from 1652; The British from 1806 (with some interesting switches in-between); South Africa became a Union in 1910; the National Party came into power in 1948; South Africa became a Republic in 1961; and the first democratic government was elected in 1994. But the Huguenots did have a significant influence on at least a section of the South African society initially as refugees, and later as part of the new order.

\section{The Huguenots: Beginnings OF A NEW ORDER}

The third panel on the wall of remembrance depicts a group of people that have formed a new community and have stabilized in their new environment. In contrast to the fear and panic of the flight on the left panel, this panel exudes an atmosphere of peace and security. The soldiers in the background have taken off their hats - one actually seems to be waving with it. A man sits in the centre, reading from the Bible to those gathered around him, openly practising the freedom of religion for which the Huguenots left their country. Others sit at his feet, listening attentively, praying. The boy with his dog is here again, but the body of the dog is relaxed, at home. While the figures on the left panel are in flight mode, those on the right are in dialogue, expressing the new community that has been formed.

The social impact of the Huguenots as a religious community in South Africa should not be underestimated - although they formed a minority group within the colonial body of the time. ${ }^{21}$ The list of their contributions is quite impressive. They brought their distinct Calvinist spirituality with them - so much so that it has been said that the legacy of Calvin was nowhere kept alive so vibrantly as in South Africa, especially in its emphasis on freedom of religion and perhaps because Calvin understood the plight of being a refugee existentially. ${ }^{22}$ Ironically enough, although the French language was denied its place by the Dutch Government, and French was no longer used in the schools and churches after the third generation, the Huguenots played a significant role in the later "Taalbeweging", i.e. the campaign to promote Afrikaans as language, with SJ du Toit, a Huguenot descendant, playing a pivotal role in this regard. The first minister of the French, Pierre Simond, re-rhymed the psalms for usage in worship services - contributing to the church musical culture of today. The French had an impact on education and the building of schools, with the Huguenot College in Wellington still existing today as reminder of that heritage. Although it is a debatable point to what extent the

20 Sometimes it took up to 30 years to legalize ownership. Some French farmers received ownership only post mortem! Cf. Coertzen, Die Hugenote, 89.

21 Totaling about $12 \%$ of that population (although some scholars estimate this to be up to $23 \%$ ), with the Dutch about $41 \%$, the Germans $37 \%$, and between $4 \%$ and $5 \%$ other nationalities. Cf. Coertzen, Die Hugenote, 145.

22 Cf. Coertzen, Die Hugenote, 143-152. 
NGTT Deel 54, Nommers $3 \& 4$, September en Desember 2013

French influence can be detected in the architecture of those and later times, many buildings, churches, schools, roads and even a tunnel bear the name Huguenot.

Perhaps one can speak in general of the aesthetical spirit of the Huguenots having an impact on culture. Although the French did not build permanent dwellings during the early years (as they were not sure whether they would or could in fact stay in South Africa), their aesthetical influence filtered through in later architecture, some forms of which can be described as a reinterpretation of symbols and traditions. A case in point could be the so-called Cape Baroque style of architecture, in which one can detect both integration and transformation of the classic Baroque style. In these buildings (for instance in the Dutch Reformed "Moederkerk" or Mother Church in Stellenbosch) one sees Baroque stripped of its romanticised excesses to form a simplified version that reflects the harsh realities of Africa. Many examples of this reinterpreted Baroque style can still be found, especially in the Cape region.

Although the French influence on the Cape Baroque style of architecture cannot be proven directly, there is no doubt that the Huguenots made a major contribution to the development of the wine industry in South Africa! Some of the best and most famous wine farms still bear French names like La Dauphiné, La Provence, Bourgogne, L'Arc de Orleans, Le Plessis Marle, Laborie, Languedoc, Non Pareille, Fleurbaix,, Montpellier, etc. The French flair of the spirit of the Huguenots cannot be denied here - even the way in which the geographical space was used to place the buildings and cultivate the land in relation to the surrounding mountains was intended to compliment the milieu as a type of iconic unity.23 The farm Boschendal24 is a prime example of this French finesse that placed the art of wine-making within a new culture, and the cultivating of the farms within a new understanding of space and style. While the Dutch East India Company saw wine-making solely in terms of a market-driven and utilitarian perspective, the French brought flair and finesse, changing wine-making into an aesthetical art.

The descendants of the Huguenots have indeed played a varied and often pivotal role in South African history. In recent history, they seemed to operate in almost all spheres of life - and often in stark opposition to one another. Amongst these names you will find, for instance, that of DF Malan (the "grandfather" of apartheid), but also of Beyers Naudé (the religious leader well known for his opposition to apartheid). You will stumble upon names like that of Charlize Theron (South African born actress, and Oscar winner), of FW de Klerk (former president of South Africa), and of Sarel Cilliers (religious leader of the Voortrekkers). And so the list goes on.

Perhaps the identity of the Huguenots as a new communitas can best be described in the words inscribed at the Huguenot Monument in Franschhoek:

"With its simplicity and graceful lines the monument has French historical character. The figure of a woman with a bible in her right hand and a broken chain in her left hand personifies the spirit of religious freedom. The French lily (fleur-de-lis) on her dress is a sign of her nobility of character and spirit. She throws off the cloak of oppression to stand in freedom of spirit above the earth. Her eyes are fixed on a vision of the great things to come. At the depicted southern tip of Africa, to which the Huguenots came in small and

23 The farms buildings are always placed so they have maximum views of the surrounding mountains, and are approached by impressive driveways flanked with rows of tree - creating expectancy as one approaches the farm building.

24 Originally a Dutch named farm, but later allocated to French farmers. 
NGTT: Oopbron - http://ngtt.journals.ac.za

unsteady ships, appears the symbols of their religion - the Bible; art and culture - a harp; agriculture and viticulture - an ear of wheat and vine - and industry - a spinning wheel. The three impeccable arches symbolize the Trinity. Above them shines the sun of justice and above that is the cross as the symbol of the Christian religion. In the pool with its reflection and in the colonnade in the background is found the spiritual bliss and peace of mind won after much struggle and turbulence." ${ }^{25}$

It is clear that the Huguenots became a stable community after the phase of liminality. Eventually, they were fully integrated into the colonial set-up in South Africa. We have already noted that, according to the theory of Turner, a new communitas that is formed often needs to be deconstructed again. This is also true of the "new order" of which the Huguenots became a part. Although they were originally a people in diaspora, used by the Dutch East India Company for its own economic purposes, they eventually became part of the drive to colonialize South Africa - a drive that reached its pinnacle in 1948 with the political ascension of the Afrikaner National Party. It is interesting to note the date on which the Huguenot Monument in Franschhoek was inaugurated - 1948, exactly the same year that the National Party came into power! ${ }^{26}$ Perhaps there is some irony here, some paradox: the Huguenot spirit of freedom on the one hand, and the assimilation into political structures of power on the other. Somehow, it seems that the wheel had turned full cycle. Those who had fled from the misuse of (religious) power again became part and parcel of the misuse of power. Let me illustrate this point with the help of another historical example, namely that of Sarel Cilliers.

Sarel Cilliers was the undisputed religious leader of the Voortrekkers, as well as the driving force behind the so-called Covenant that was made between the Voortrekkers and God after a victorious battle against the Zulus. Part of the Covenant was the promise to celebrate the day of this victory for generations to come, as if it was a Sabbath. Thus the Day of the Covenant became a religious festival upheld by a section of the Afrikaner people - before being changed after 1994 into a public holiday known as The day of Reconciliation (16 December).

Cilliers was described as a man with strong religious convictions, a pious character - and somewhat fearsome. He regularly preached fire and brimstone to those who dared to partake in dance parties and he passionately detested any new form of fashion. ${ }^{27}$

In his journals, Sarel Cilliers often thanked God for military victories, for instance against Mzilikazi in $1837 .{ }^{28} \mathrm{He}$ writes: "We were driven by perils to undertake a campaign with 107 men against the mighty enemy and our God gave them into our hands so that we greatly defeated them and took 6000 cattle from them and not one of us was lost."29 And again, eight months later, after another clash with the warriors of Mzilikazi: "On this day the Lord our God has again given them into our hands... so that we brought them into submission and more than 3000 of them fell in battle and they left their land and what was theirs became ours." ${ }^{\prime 3}$

25 Also quoted in Coertzen, The Huguenots: Origins, 22.

26 The discourse between Coertzen and Denis again becomes relevant here. Cf. footnote 3 at the beginning of this article.

27 Cf. Karel Schoeman, Die wêreld van Susanna Smit 1799-1863 (Kaapstad: Human \& Rousseau, 1995), 120.

28 Mzilikazi was a famous indigenous warrior of the time.

29 Quoted from AJ Kannemeyer, Hugenote-Familieboek (Kaapstad: Struik, 1940), 32. Translation mine.

30 Quoted from Kannemeyer, Hugenote-Familieboek, 32-33. Translation mine. 
NGTT Deel 54, Nommers $3 \& 4$, September en Desember 2013

This is the painful irony, the inexplicable paradox: a descendant of the Huguenots who were driven out of their homeland in the name of God, in turn became part of a system that repeated history: again driving the "other" away, marginalising, exploiting them - in the name of God. Obviously one should, also in this instance, take the warning of a responsible, hermeneutical dialogue with the past seriously. It is always a risky enterprise to interpret the past, even, and perhaps especially with the hindsight of retrospection. History is more nuanced, contextual, and multi-layered than we normally tend to suspect. Mzilikazi was, for instance, not innocent in the unfolding of these clashes between Voortrekkers and indigenous people. His name, roughly translated, means something like"path of blood". He was infamous for the slaughtering of many smaller tribes in his own quests for power. ${ }^{31}$ But this seems to be the inescapable "lesson" that this part of history teaches us - the frightening link between religion and power.

\section{RetrospeCtiOn: RELIGION AND POWER}

It is clear from this history that power always seems to play a fundamental role in religion. Power, however, can be a vague and complex concept, making it virtually impossible to find two thinkers who agree about its nature. ${ }^{32}$ Power can be described from political, social, military, ideological, cultural, theological, and numerous other perspectives. It can be portrayed as conceptual, behavioral, and relational control. Although power can be understood as occasional and discretionary, contemporary thinkers have drawn attention to the ubiquitous nature of power - the fact that power is omnipresent and its operation inevitable. ${ }^{33}$

Power as such need not be evil or destructive. As a matter of fact, it can simply be described as a "communication of efficacy,"34 or perhaps as adiaphoron (neutral reality). Power can be used for good (e.g., the doctor's "power to heal") or evil. Power itself is neutral and formal, almost indifferent. However, it seldom remains indifferent. It becomes good and necessary, but also bad, excessive, or abusive, through the objects applying it or to which it is applied. ${ }^{35}$

The church, and perhaps especially the church, also suffers from a tendency to fall prey to ideologies of power, which have been described as kyriarchy - "the multiple and complex systemic grading of dominations, subordinations, and power arrangements. ${ }^{\prime 36}$ The church, as representative of the power of God, often tends to mistake itself (its structures, officials, theology) as the final form of knowledge, if not God as such. It often positions itself in a dominating and controlling position within the networks and gradations of those who have power and those deemed to be without power. It often marginalizes, instead of siding with the marginalized. ${ }^{37}$

31 It is not possible to do justice to this history within the limitations of this article. For an overview, cf.

Peter Becker, Path of Blood. Rise and Conquests of Mzilikazi, $2^{\text {nd }}$ edition (London: Penquin Books, 1979).

32 Kyle A. Pasewark, A Theology of Power: Being Beyond Domination (Minneapolis: Fortress, 1993), 1.

33 Cf. Pasewark, A Theology of Power, 1.

34 Pasewark, A Theology of Power, 5.

35 Pasewark, A Theology of Power, 3.

36 Flora A. Keshgegian, Redeeming Memories: A Theology of Healing and Transformation (Nashville: Abingdon, 2000), 27.

37 On the other hand, preaching against these powers is nothing new in South Africa - think of people like Desmond Tutu, Beyers Naudé, and Allan Boesak, whose sermons have been well documented for generations to come. Their sermons were described as subversive by those in power. Through the power of their preaching, the complacency of the status quo was challenged; the powers that dehumanized South Africans, as well as those powers that were "institutionalized" and for many seemed "in order," whether they were political, social or religious, were unmasked and dismantled. Cf. Hendrik J. C. Pieterse, ed., 
NGTT: Oopbron - http://ngtt.journals.ac.za

Religion can be a powerful force - whether constructive or destructive. Without a doubt the God-images that underline religion are of importance here. The question is whether certain God-images strengthen the habitus of imperialism, and consequently fall prey to nationalistic, ethnic, or religious justifications of power and the chilling suggestion, if not blatant proposition, that those in power have God on their side. ${ }^{38}$

But God does not side with the mighty. ${ }^{39}$ God's strange might does not exclude those on the margins of power, but rather includes them; does not stretch out a threatening hand that drives away - as on the left side of the wall of remembrance - but rather embraces and forms community - as on the right side of the wall of remembrance. One is reminded of the words of Miroslav Volf, who proposes the idea of embrace as a theological response to the problem of exclusion. He argues that "exclusion" of people who are alien or different is among the most intractable problems in the world today. He writes, "It may not be too much to claim that the future of our world will depend on how we deal with identity and difference. The issue is urgent. The ghettos and battlefields throughout the world - in the living rooms, in inner cities, or on the mountain ranges - testify indisputably to its importance." 40

To change the hand that drives away into hands that embrace - hopefully religion can help to shape, perhaps even save, the future of our societies in this way. And perhaps this is the important lesson to be learned from the early Huguenots. They were never in official positions of power, but had a different type of "power", with an undeniable influence on South African society - the power of the aesthetics of the Huguenot spirit.

Aesthetics is, inter alia, about healing, one could say about the integration of life. But that can also be said about religion, as a matter of fact, the original meaning of the concept "religion" has been traced back to the linguistic roots of ligature, which basically means a tying together of significances. ${ }^{41}$ Herein lies the "power" of religion: it does not scatter, but rather gathers; does not chase away, but rather calls together, ties together - in order to form a new and integrated significance. Perhaps the Huguenots helped us with this: showing us how to become connoisseurs of life - wherein lies the power of their religion.

This notion of being a connoisseur of life should however not be understood in an elitist manner. It rather resonates with a current trend in Practical Theology that speaks about "gelebte Religion" (lived religion). ${ }^{42}$ Religion that is lived is spread out across the entirety of

Desmond Tutu's Message: A Qualitative Analysis (Kampen: Kok; Weinheim: Deutscher Studien, 1995); Allan Boesak, Die Vinger van God: Preke oor Geloof en die Politiek (Johannesburg: Ravan, 1979); Len Hansen, ed., The Legacy of Beyers Naude (Stellenbosch: Sun Press, 2005), to name but a few sources.

38 Cf. the discussion in L. Susan Bond, Trouble with Jesus: Women, Christology, and Preaching (St Louis:

Chalice, 1999), 131; also Günther Schiwy, Abschied vom allmächtigen Gott, (München: Kösel, 1995), 61.

39 One is reminded of President Zuma's recent claims that God is on the side of the ANC, being there since its conception, and that the ANC will rule until "Jesus comes again". Does this not represent a God-image of "being on our side"? A God that can be "called in" to legitimize the search for and stabilization of power?

40 Miroslav Volf, Exclusion \& Embrace: A Theological Exploration of Identity, Otherness, and Reconciliation (Nashville: Abingdon, 1996), 57f.

41 Daniël Louw, Cura Vitae. Illness and the healing of life in pastoral care and counselling. A Guide for Caregivers (Wellington: Lux Verbi.BM, 2008), 49.

42 Cf. Martina Kumlehn, "Praktische Theologie als Lebenswissenschaft?” In Lebenswissenschaft Praktische Theologie? Ed. Thomas Kie, Martina Kumlehn, Ralph Kunz, Thomas Schlag (Berlin/New York: Walter de Gruyter, 2011), 1-10. 
NGTT Deel 54, Nommers 3 \& 4, September en Desember 2013

life; it holds all the creases and folds of our existence in view. It therefore entails (aesthetic) processes such as observation, interpretation, anticipation, and also transformation of life but never in a manner that enforces or excludes by means of power. ${ }^{43}$ Perhaps the contribution of the Huguenots could indeed be described as such: aesthetic connoisseurs of life, living their religion.

\section{KEYWORDS}

Religious communities

liminality

Huguenots

society

power

\section{SLEUTELWOORDE}

Godsdienstige gemeenskappe

liminaliteit

Hugenote

samelewing

mag

43 Cf. Johan Cilliers, Dancing with Deity: Re-imagining the Beauty of Worship (Wellington: Bybel-Media, 2012), 132ff. Also Johan Cilliers, Fides quaerens societatem: Praktiese Teologie op soek na sosiale vergestalting. Tydskrif vir Geesteswetenskappe (2009), 49/4:624-638. 